\title{
Cytotoxic and toxicogenomic effects of silibinin in bladder cancer cells with different TP53 status
}

\author{
Daiane Teixeira de Oliveira ${ }^{1, \dagger}$, André Luiz Ventura Sávio ${ }^{2, \dagger}$, \\ João Paulo de Castro Marcondes ${ }^{2,3}$, Tatiane Martins Barros ${ }^{l}$, Ludmila Correia Barbosa ${ }^{l}$, \\ Daisy Maria Favero Salvadori ${ }^{2}$ and Glenda Nicioli da Silva ${ }^{1, *}$ \\ ${ }^{1}$ Escola de Farmácia, Departamento de Análises Clínicas, \\ Universidade Federal de Ouro Preto, Ouro Preto, MG, Brazil \\ ${ }^{2}$ Faculdade de Medicina de Botucatu, Departamento de Patologia, \\ Universidade Estadual Paulista, Botucatu, SP, Brazil \\ ${ }^{3}$ Instituto de Biociências de Botucatu, Departamento de Genética, \\ Universidade Estadual Paulista, Botucatu, SP, Brazil \\ *Corresponding author (Email, glenda_silva@yahoo.com; nicioli@ef.ufop.br) \\ ${ }^{\dagger}$ These authors contributed equally to the work.
}

\begin{abstract}
Silibinin is a natural phenol found in the seeds of the milk thistle plant. Recent data have shown its effectiveness for preventing/treating bladder tumours. Therefore, in this study we investigated the cytotoxic and toxicogenetic activity of silibinin in bladder cancer cells with different TP53 statuses. Two bladder urothelial carcinoma cell lines were used: RT4 (wild-type TP53 gene) and T24 (mutated TP53 gene). Cell proliferation, clonogenic survival, apoptosis rates, genotoxicity and relative expression profile of FRAP/mTOR, FGFR3, AKT2 and DNMT1 genes and of miR100 and miR203 were evaluated. Silibinin promoted decreased proliferation and increased late apoptosis in TP53 mutated cells. Increased early apoptosis rates, primary DNA damage, and decrease of cell colonies in the clonogenic survival assay were detected in both RT4 and T24 cell lines. Down-regulation of FRAP/mTOR, AKT2, FGFR3, DNMT1 and miR100 expression occurred in RT4 cells. Modulation of miR203 was observed in both cell lines. In conclusion, despite the reduction of clone formation in both cell lines, the toxicogenomic effect of silibinin on $F R A P / \mathrm{mTOR}$, $A K T 2, F G F R 3, D N M T 1$ and $m i R 100$ was dependent on the TP53 status. Taken together, the data confirmed the role of silibinin as an antiproliferative compound, whose mechanism of action was related to the TP53 status.
\end{abstract}

[de Oliveira DT, Sávio ALV, de Castro Marcondes JP, Barros TM, Barbosa LC, Salvadori DMF and da Silva GN 2017 Cytotoxic and toxicogenomic effects of silibinin in bladder cancer cells with different TP53 status. J. Biosci. 42 91-101]

\section{Introduction}

Among urinary bladder tumours, urothelial cell carcinoma (UCC) is one of the most common malignancies, with high prevalence especially in industrialized countries (Jemal et al. 2007). The most frequent gene mutations found in these bladder carcinoma cells occur in TP53 and are related to the cell transformation, malignancy and high recurrence rates (Cheng et al. 2011). Numerous studies have demonstrated the relationship between TP53 or p53 mutations and the poor response to antineoplastic therapies (Saint et al. 2004; Esuvaranathan et al. 2007). At present, only tumour grade and stage determine the treatment's protocols, including surgery, immunotherapy, radiotherapy and chemotherapy, for improving UCC management (Mayr et al. 2014; Patel et al. 2015). Transurethral resection is the gold standard intervention for non-muscle invasive UCC, followed by adjuvant intravesical therapy with Bacillus Calmette-Guerin

Keywords. Bladder cancer; cell proliferation; genotoxicity; PI3K/AKT/FRAP-mTOR pathway; silibinin; TP53 gene 
(van Lingen et al. 2013). Topical chemotherapy with mitomycin, thiotepa and epirubicin has also been used as an alternative treatment, but it has no impact on long-term survival, disease progression and recurrence (Retz et al. 2013). Additional treatment protocols for UCC include MVAC, a combination of methotrexate, vinblastine, doxorubicin and cisplatin, and the combination of gemcitabine and cisplatin (Raghavan et al. 2012).

However, despite their effectiveness, some antineoplasic drugs have limited use because of their adverse side effects, including neurotoxicity, nephrotoxicity, myelosuppresion, etc. (Li et al. 2015; Sinha et al. 2015). Therefore, treatment improvement with use of alternative compounds to reduce these undesirable effects has become imperative. Because of their wide spectrum of chemical and biological properties, some plants have been studied to identify natural compounds with potential antitumour activity (Dumont et al. 2007; Chawla et al. 2010). Recent findings about complementary and alternative medicine for prostate and bladder cancer treatment have shown that curcumin, resveratrol and silibinin have potential anticancer properties through multiple molecular targets (Philippou et al. 2013). Silibinin, one of the less investigated compound, is a natural phenol of the flavonolignan family, and is derived from the seeds of the milk thistle (Silybum marianum; Asteraceae) plant (Tyagi et al. 2007). This substance is effective in preventing the recurrence of superficial bladder tumours in mice (Zeng et al. 2011), in addition to its broad-spectrum efficacy against prostate cancer progression both in vitro and in vivo models without noticeable toxicity (Ting et al. 2013). However, little is known about the safety, efficacy, cost-effectiveness and mechanism of action of these phytochemicals (Philippou et al. 2013).

Indeed, it is known that some dietary and natural compounds may regulate gene expression by modulating DNA methylation profile (Zwergel et al. 2016), mRNAs (Sávio et al. 2015) and microRNAs (miRNAs or miR) (Ahmad et al. 2012) expressions. DNA methylation is a genetically programmed modification catalysed by DNA methyltransferases (DNMTs). Although DNA methylation is essential for embryonic development or cell differentiation, aberrant expression and/or activities of DNMTs are involved in several diseases, including several cancer types (Zwergel et al. 2016). Recently it was demonstrated that both green tea, polyphenol epigallocatechin 3-gallate, and kazinol Q, a natural product from Formosan plants, inhibited DNMT expression and suppressed colon HCT 116, breast MCF-7 and prostate LNCaP cancer cell proliferation, respectively (Moseley et al. 2013; Weng et al. 2014). Additionally, recent reports have shown that TP53 inactivation may alter the DNA demethylation process through regulation of TDG (thymine DNA glycosylase), a base excision repair gene (Maiti and Drohat 2011; da Costa et al. 2012). Recently it was demonstrated that silibinin could inhibit DNMT activity in colon cancer cell lines (Kauntz et al. 2013). Moreover, such a compound alone or in association with histone deacetylators or DNMT inhibitors can restore the methylated-inhibited E-cadherin gene expression, decreasing the migratory and invasive potential of non-small-cell lung carcinoma cell lines (Mateen et al. 2013).

Another gene regulation mechanism now widely studied is mediated by miRNAs. These are small noncoding RNAs that direct gene regulation through translational repression and/or degradation of complementary mRNA ( $\mathrm{Wu}$ and Belasco 2008). Growing evidence has suggested that miRNAs are implicated as oncogenes and tumour suppressors in a variety of human cancers, and that more than $50 \%$ are located in cancer-associated genomic regions or in fragile sites (Bartel 2004; Aravindaram and Yang 2010). Furthermore, the TP53 gene may facilitate the processing of primary miRNAs to precursor miRNAs through interaction with Drosha processing (Suzuki et al. 2009). Interference of miR100 and miR203 in tumour cells has been strengthened by the identification of their targets, which play important role in regulation of cell growth, cellular proliferation and senescence (Nagaraja et al. 2010). Among those targets are genes related to the PI3KFRAP/mTOR or PI3K/AKT2 pathways, associated with a majority of sporadic human cancers, such as breast, ovarian and bladder cancers (Gingras et al. 2001; Luo et al. 2003; Shaw and Cantley 2006; Dobbin and Landen 2013; GonzalezAngulo and Blumenschein 2013).

Therefore, given the evidence of urothelial antineoplastic potential of silibinin, and taking into account that its mechanism of action is not completely understood, this study aimed to investigate the molecular events underlying the antiproliferative activity of silibinin in bladder cancer cell lines with wild-type (RT4) and mutated (T24) TP53 gene.

\section{Materials and methods}

\subsection{Cell lines and tested compound}

The established cell lines RT4 and T24 from human bladder UCC were purchased from the Cell Bank of the Federal University of Rio de Janeiro, Brazil. No specific mutation was detected in RT4 cells, which was established from a low-grade papillary bladder tumour. The T24 cells were obtained from an invasive tumour with a TP53 allele encoding an in-frame deletion of tyrosine 126 . The cell lines were maintained as previously described by (da Silva et al. 2010). Silibinin (CAS Number 22888-70-6) was purchased from Sigma-Aldrich (USA) and diluted into 2\% dimethyl sulphoxide (DMSO), prior to use.

\subsection{Cell proliferation}

Cytotoxicity and cell proliferation rates were assessed using the Cell Proliferation Kit II (XTT) from ROCHE Diagnostics 
(Mannheim, Germany). Briefly, cells were seeded into 12 well culture plates $\left(6 \times 10^{4}\right.$ cells/well $)$ and were treated $24 \mathrm{~h}$ later with different concentrations of silibinin $(100,115,130$, 150,200 and $250 \mu \mathrm{M}$ ) for $48 \mathrm{~h}$ (cell proliferation). Untreated cells and cells treated only with DMSO were cultured as negative controls. After treatment, cells were washed with Hank's solution $\left(0.4 \mathrm{~g} \mathrm{KCl}, 0.06 \mathrm{~g} \mathrm{KH}_{2} \mathrm{PO}_{4}, 0.04 \mathrm{~g}\right.$ $\mathrm{Na}_{2} \mathrm{HPO}_{4}, 0.35 \mathrm{~g} \mathrm{NaHCO}_{3}, 1 \mathrm{~g}$ glucose and $8 \mathrm{~g} \mathrm{NaCl}$ in 1 $\mathrm{L}_{2} \mathrm{O}$ ) and then a $50 \mu \mathrm{L}$ aliquot of XTT solution ( $1 \mathrm{~mL}$ XTT labelling solution $/ 20 \mu \mathrm{L}$ of electron-coupling reagent) was added to each well. The absorbance was measured at 492 and $690 \mathrm{~nm}$ after $40 \mathrm{~min}$ (absorbance results are proportional to the percentage of viable cells). Treatments were performed in triplicate.

\subsection{Clonogenic survival}

Clonogenic assay was performed for evaluating the longterm effects of silibinin. To determine clonogenic ability, cells were plated at a density of $1 \times 10^{6} / 25 \mathrm{~cm}^{3}$ culture flask. After $24 \mathrm{~h}$, silibinin $(100,115,150$ and $200 \mu \mathrm{M})$ was added to the culture medium and cells incubated again at $37^{\circ} \mathrm{C}, 5 \%$ $\mathrm{CO}_{2}$, for $24 \mathrm{~h}$. Afterwards, cultures were rinsed with Hank's solution and trypsinized. Approximately 1000 cells were plated into $25 \mathrm{~cm}^{3}$ culture flasks and allowed to grow for 15 days to form colonies. Cells were stained with Giemsa, and colonies with 50 or more cells were counted. Silibinin treatments and controls were performed in triplicate.

\subsection{Comet assay}

The Comet assay was carried out according to the technique described by Singh et al. (1988) and Tice et al. (1991). The alkaline version used was able to detect DNA strand breaks and alkaline-labile sites (ALS) in DNA. Initially, $6 \times 10^{4}$ cells were seeded into 12 -well plates for $24 \mathrm{~h}$. Then, cells were treated with silibinin at concentrations of $100,115,130$ and $150 \mu \mathrm{M}$ for $24 \mathrm{~h}$. Treatment with $0.006 \mathrm{M}$ methyl methanesulfonate (Sigma-Aldrich, Inc.; St. Louis, MO, USA) for $5 \mathrm{~min}$ at $37^{\circ} \mathrm{C}$ was used as positive control. Briefly, $10 \mu \mathrm{L}$ of cells were added to $100 \mu \mathrm{L}$ of $0.5 \%$ low-melting-point agarose at $37^{\circ} \mathrm{C}$. This mixture was layered onto pre-coated slides with $1.5 \%$ standard agarose and covered with a coverslip. The agarose was allowed to solidify at $4{ }^{\circ} \mathrm{C}$, and then, the coverslip was gently removed. Afterwards, the slides were immersed into lysis solution $(2.5 \mathrm{M} \mathrm{NaCl}, 100 \mathrm{mM}$ EDTA, $10 \mathrm{mM}$ Tris- $\mathrm{HCl}$ at $\mathrm{pH} 10,1 \%$ sodium sarcosinate, $1 \%$ Triton $\mathrm{X}-100$ and $10 \%$ DMSO) overnight at $4{ }^{\circ} \mathrm{C}$, and then incubated in an alkaline buffer $(0.3 \mathrm{mM} \mathrm{NaOH}$ and $1 \mathrm{mM}$ EDTA; $\mathrm{pH}>13$ ) for 20 min to allow DNA unwinding and alkali-labile site expression. Electrophoresis was conducted in the same alkaline buffer at $4^{\circ} \mathrm{C}$, for $20 \mathrm{~min}$, at $25 \mathrm{~V}$ $\left(0.86 \mathrm{~V} \mathrm{~cm}^{-1}\right)$ and $300 \mathrm{~mA}$. After electrophoresis, the slides were neutralized in $0.4 \mathrm{M}$ Tris- $\mathrm{HCl}(\mathrm{pH} 7.5)$ solution for 15 min, fixed with absolute ethanol and stored at room temperature until analysis. All steps were conducted in the dark to prevent any additional DNA damage. The slides were stained with SYBR Gold (1:10,000; Invitrogen, NY), immediately before analysis. Cell viability was assessed using the trypan blue ( $0.4 \%$ trypan blue; Sigma-Aldrich, Inc., St. Louis, MO) exclusion test, and was never below $90 \%$. A total of 150 randomly selected nucleoids per treatment were analysed under $400 \times$ magnification, in a fluorescence microscope connected to an image analysis system (Comet Assay IV, Perceptive Instruments; Suffolk, Haverhill, UK). Tail intensity (\% DNA in tail) was used to estimate DNA damage. The slides were prepared in duplicate from three independent treatments.

\subsection{Apoptosis assay}

A quantitative assessment of apoptosis was performed using a Guava Annexin reagent (Merck Millipore). Annexin V was used for detecting the externalization of phosphatidylserine to the cell surface and 7-AAD as an indicator of cell membrane structural integrity. Briefly, $2 \times 10^{5}$ cells were seeded into a $25 \mathrm{~cm}^{3}$ culture flask. After $24 \mathrm{~h}$, the cells were treated with silibinin at concentrations 100,150, 200 and $250 \mu \mathrm{M}$ for $48 \mathrm{~h}$. Untreated cells and cells treated with only DMSO were cultured as controls. Afterwards, cells were washed with Hank's solution, trypsinized, resuspended into $100 \mu \mathrm{L}$ Guava Nexin reagent for $20 \mathrm{~min}$ in the dark, and immediately analysed in the Guava easyCyte flow cytometer (Millipore) using the Guava System software. Data from 5000 cells were collected in each data file. Cellular status was defined as follows: unstained cells were classified as 'alive'; cells stained by only annexin $\mathrm{V}$ were classified as 'early apoptotic'; cells stained by both annexin V and 7AAD were classified as 'late apoptotic'; and cells stained by only 7-AAD were classified as 'dead'.

\subsection{FRAP/mTOR, FGFR3, DNMT1 and AKT2 gene expression}

Cells were seeded into plates at a density of $1 \times 10^{6}$ cells/plate. Twenty-four hours later, cells were treated with silibinin $(135,150$ and $200 \mu \mathrm{M})$ for $24 \mathrm{~h}$. Afterwards, cells were washed with Hank's solution and collected for miRNA and RNA extraction. Total RNA was isolated using the RNeasy Mini kit ${ }^{\circledR}$ (Qiagen), according to the manufacturer's instructions. RNA concentrations and purities were determined using a NanoVue spectrophotometer (GE Healthcare). Reverse transcription was performed using $6 \mu \mathrm{L}$ of random hexamer primers $(10 \times), 6 \mu \mathrm{L}$ of reaction buffer $(10 \times), 2.5 \mu \mathrm{L}$ 
of dNTPs $(25 \times)$ and $3 \mu \mathrm{L}$ of MultiScribe $(50 \mathrm{U} / \mathrm{mL}$; High Capacity, Applied Biosystems, Foster City, CA). After incubation $\left(25^{\circ} \mathrm{C}\right.$ for $10 \mathrm{~min}, 37^{\circ} \mathrm{C}$ for $2 \mathrm{~h}$ and $4^{\circ} \mathrm{C}$ undetermined), cDNA was stored at $-20^{\circ} \mathrm{C}$. FRAP/mTOR (Hs_00234508_m1), FGFR3 (Hs00179829_m1), DNMT1 (Hs00945875_m1) and AKT2 (Hs01086102_m1) gene expressions were assayed using the TaqMan system (Applied Biosystems). Each tube contained $2 \mu \mathrm{L}$ cDNA template, $5 \mu \mathrm{L}$ Master Mix TaqMan 2X (Applied Biosystems) and $0.5 \mu \mathrm{L}$ of $20 \times$ primers/probe (Assays-onDemand gene expression products; Applied Biosystems). $G A P D H$ was used as a housekeeping gene. The reaction was performed using the following thermal cycler conditions: $94^{\circ} \mathrm{C}$ for $10 \mathrm{~min}$ followed by 40 cycles at $94^{\circ} \mathrm{C}$ for $30 \mathrm{~s}$ and $60^{\circ} \mathrm{C}$ for $1 \mathrm{~min}$. Fluorescence data were collected during each annealing/extension step. The reactions were performed using the Applied Biosystems 7500 FAST RealTime PCR System and the SDS software, version 1.2.3 (Sequence Detection Systems 1.2.3, 7500 Real-Time PCR Systems; Applied Biosystems). For every PCR sample, a negative (no template) control was processed as a routine control. Relative gene expression data were analysed using the $2^{-\Delta \Delta \mathrm{CT}}$ method (Livak and Schmittgen 2001). Each silibinin treatment was performed in triplicate. The interaction network was created using String 10 software ( $h t t p: / /$ string-db.org/newstring_cgi/show_network_section.pl). The active prediction method used was the Experiments, with confidence score of 0.400 .

\section{7 miR100 and miR203 expression}

miRNA was isolated using the miRNeasy kit ${ }^{\circledR}$ (Qiagen), according to the manufacturer instructions. Complementary DNA was synthesized using the TaqMan Assays Small RNA kit, according to the manufacturer's protocol $(0.15 \mu \mathrm{L}$ $100 \mathrm{mM}$ dNTPs, $1 \mu \mathrm{L}$ MultiScribe ${ }^{\mathrm{TM}}$ reverse transcriptase $50 \mathrm{U} / \mu \mathrm{L}, 1.50 \mu \mathrm{L}$ reverse transcription buffer $10 \times, 0.19 \mu \mathrm{L}$ RNase inhibitor $20 \mathrm{U} / \mu \mathrm{L}, 4.16 \mu \mathrm{L}$ DNAse and RNAse free water, $3 \mu \mathrm{L}$ RT primer $5 \times$ and $5 \mu \mathrm{L}$ miRNA sample; Applied Biosystems).

miR100 (2142) and miR203 (000507) expressions were assayed using the TaqMan system (Applied Biosystems). Quantitative PCR was performed in an automatic thermocycler (ABI Prism 7500 Sequence Detection System; Applied Biosystems), using 1.0 $\mu \mathrm{L}$ TaqMan Assay Small RNA $(20 \times), 1.33 \mu \mathrm{L}$ reverse transcription product, $10 \mu \mathrm{L}$ TaqMan Universal PCR Master Mix II $(2 \times)$ and $7.67 \mu \mathrm{L}$ DNase and RNase free water, totalling $20 \mu \mathrm{L}$ per sample. $R N U 6 B$ was used as control. The reaction was performed using the following thermal cycler conditions: $94^{\circ} \mathrm{C}$ for $10 \mathrm{~min}$ followed by 40 cycles at $94^{\circ} \mathrm{C}$ for $30 \mathrm{~s}$ and $60^{\circ} \mathrm{C}$ for $1 \mathrm{~min}$. For every PCR sample, a negative control was processed. Assays were performed in triplicate. Relative gene expression data were analysed using the $2^{-\Delta \Delta C T}$ method.

\subsection{Statistical analysis}

For the cytotoxicity, cell proliferation and clonogenic survival tests, apoptosis, gene expression and comet assay, the data were analysed using the one-way ANOVA, and post hoc analysis by Tukey's test. The results were considered statistically significant with $p<0.05$. Statistical analyses were carried out using the SigmaStat Version 3.5 (Dundas Software LTD, Germany).

\section{Results}

\subsection{Silibinin inhibits human UCC growth}

As shown in figure 1, inhibited cell proliferation was observed in the T24 cell line $48 \mathrm{~h}$ after treatment with silibinin at concentrations equal to and higher than $150 \mu \mathrm{M}$. The data of the clonogenic survival assay showed significant decrease of colonies in both RT4 and T24 cell lines after silibinin treatment with all the tested concentrations, suggesting that silibinin inhibited the formation of cell colonies independent of the TP53 status (figure 2).

\subsection{Silibinin induces DNA damage}

Using Comet Assay alkaline version, increased DNA damage was detected after treatment with silibinin at $150 \mu \mathrm{M}$, in both cell lines (RT4 and T24). The comparison between the

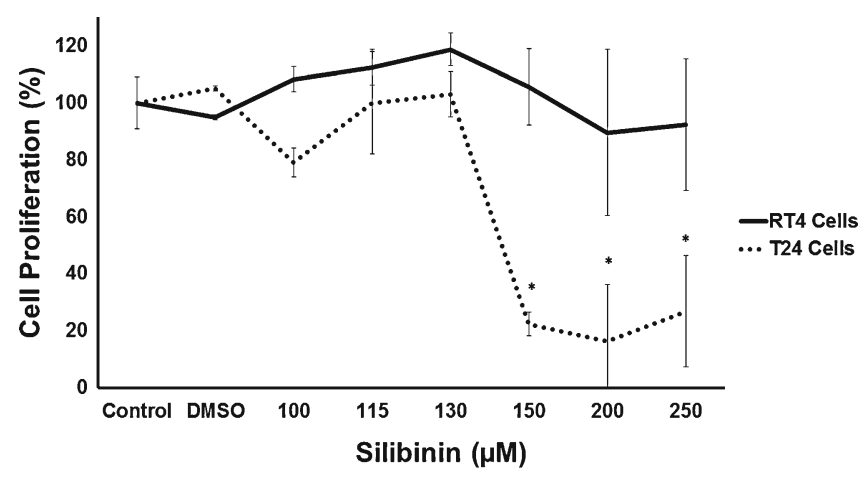

Figure 1. Percentage of cell proliferation (logarithmic scale) in the urinary bladder carcinoma RT4 and T24 lineages $48 \mathrm{~h}$ after silibinin treatment. Each point represents the mean value \pm standard deviation obtained from three independent treatments with the same concentration of silibinin. $* p<0.05$ in relation to the silibinin vehicle control ( $2 \%$ DMSO). 


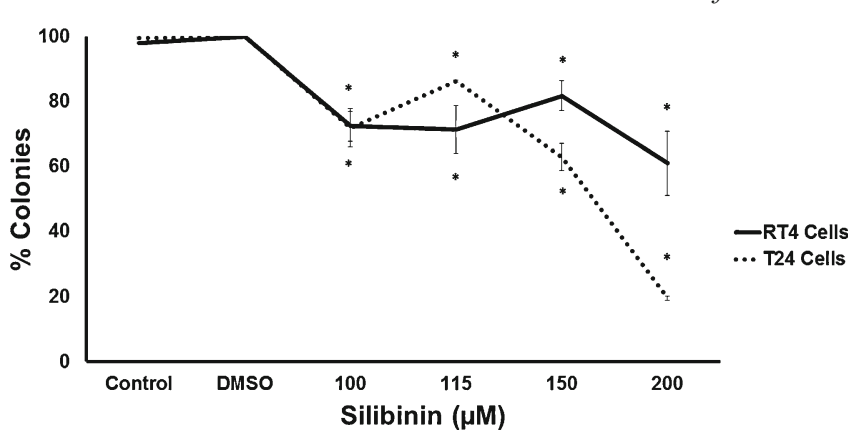

Figure 2. Percentage of colonies (logarithmic scale) in the urinary bladder carcinoma RT4 and T24 lineages 15 days after silibinin treatment. Each point represents the mean value \pm standard deviation obtained from three independent treatments with the same concentration of silibinin. ${ }^{*} p<0.05$ in relation to the silibinin vehicle control ( $2 \%$ DMSO).

two cell lines was done only for the concentration (150 $\mu \mathrm{M})$ which caused DNA damage in both. We tried to investigate whether cells presented the same sensitivity to the test compound. However, no statistically difference was detected in the amount of damage between the two lineages (figure 3).

\subsection{Silibinin induces low apoptosis rates in human UCC}

Increased amount of late (100, 150, 200 and $250 \mu \mathrm{M})$ and early $(250 \mu \mathrm{M})$ apoptosis was observed in T24 cells, $48 \mathrm{~h}$ after treatment with silibinin. For RT4 cells, high level of early apoptosis $(200 \mu \mathrm{M})$ was detected after $48 \mathrm{~h}$ (figure 4). These results suggest growth inhibition by silibinin is not related to the high apoptosis rates in UCC cells.

\subsection{Silibinin induces FRAP/mTOR, FGFR3, DNMT1, $A K T 2$ and miR100 modulation only in the wild-type TP53 human UCC}

Modulated gene FRAP/mTOR, FGFR3, AKT2 and DNMT expression was observed after exposure to silibinin These genes were altered in a majority of human cancers and play important roles in many cellular processes, including the regulation of growth. Moreover, these genes interact with TP53, which is the reason why the cell lines with different TP53 statuses were chosen. The FRAP/mTOR, FGFR3, $D N M T 1$ and $A K T 2$ genes and $m i R 100$ were down-regulated in RT4 cells after treatment with silibinin at 135, 150 and $200 \mu \mathrm{M}$. No gene modulation was detected in T24 cells (figure 5). miR203 was modulated in both cell lines after silibinin treatments (figure 6). Figure 7 depicts the network involving the investigated genes, indicating interaction
RT4 cells
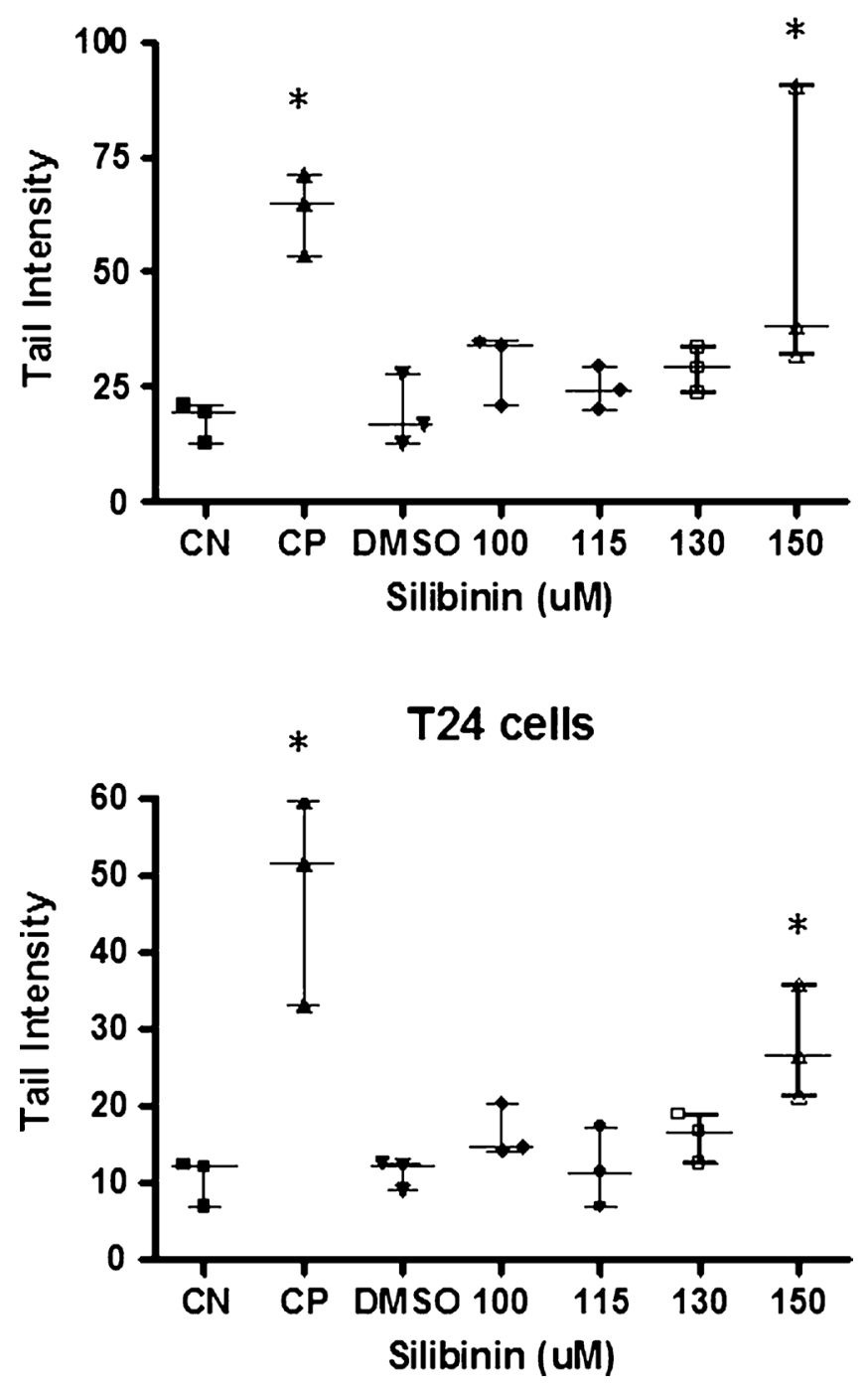

Figure 3. DNA damage (tail intensity) in RT4 and T24 bladder carcinoma cell lines after silibinin treatment. ${ }^{*} p<0.05$ in relation to the silibinin vehicle control ( $2 \% \mathrm{DMSO})$. $\mathrm{CN}$ : negative control; $\mathrm{CP}$ : positive control.

among DNMT1, TP53, FRAP/MTOR and AKT2. Taken together, these results clearly indicate that the effect of silibinin in terms of molecular mechanism is dependent on the TP53 status.

\section{Discussion}

The use of natural products for treating diseases is the oldest and most widespread form of medication (Halberstein 2005). However, limited knowledge about the effectiveness or 

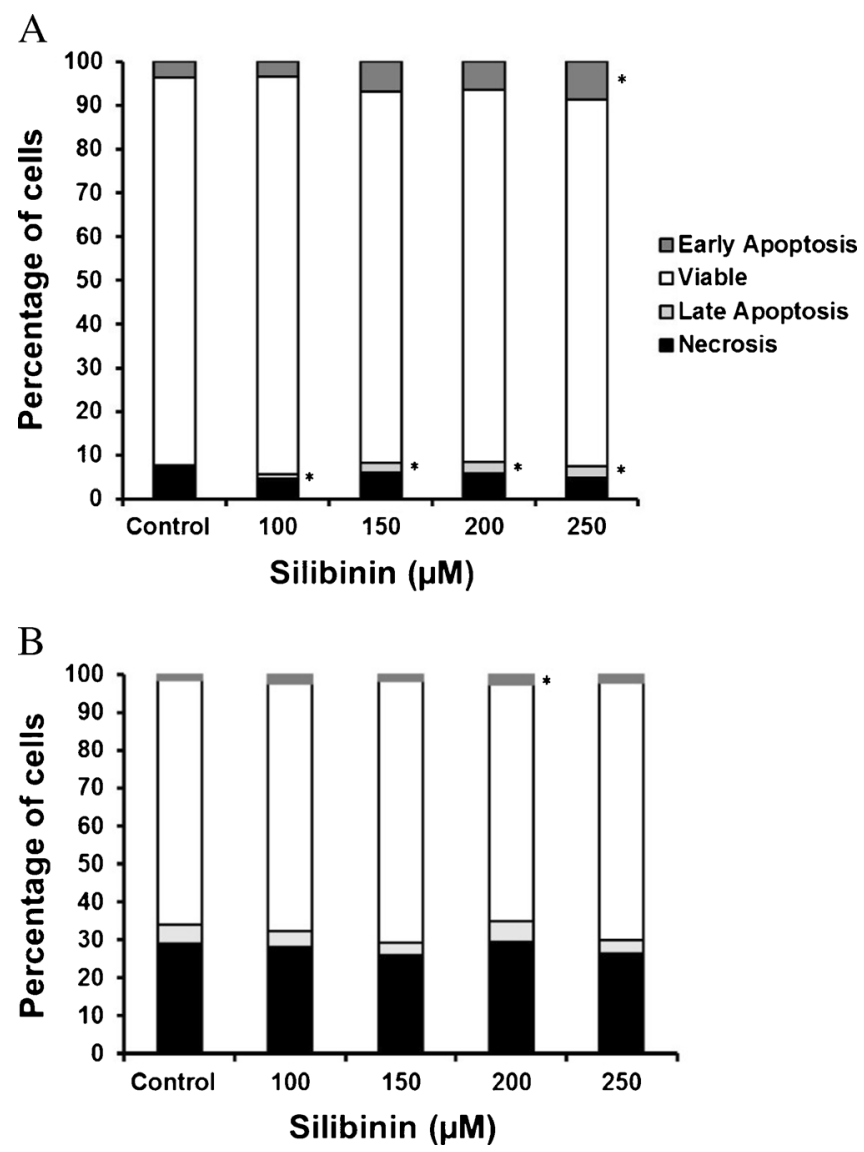

Figure 4. Percentage of cells at early and late apoptosis, viable and death (necrosis) cells in the urinary bladder carcinoma T24 and RT4 cell lines after silibinin treatments. ${ }^{*} p<0.05$ compared to the silibinin vehicle control (2\% DMSO). (A) T24 cells; (B) RT4 cells.

benefits has delayed the incorporation of such products into the clinical practice (Ahmad et al. 2012). Regarding silibinin, recent findings have supported its clinical usefulness for colorectal cancer intervention and therapy (Kumar et al. 2014). Furthermore, some studies have demonstrated its strong antiproliferative, pro-apoptotic and antiinflammatory effects, including potential to cause severe and irreparable damage to colon tumour cells (Kaur et al. 2009; Raina et al. 2013; Rajamanickam et al. 2010). In light of these, the present study focused on the molecular mechanisms related to the antiproliferative activity of silibinin in UCCs with wild-type and mutated TP53 gene.

Recent findings have demonstrated that non-muscleinvasive and muscle-invasive bladder cancers have distinct pathways in carcinogenesis. The pathway with mutation of FGF receptor 3 gives rise to low-grade non-muscle-invasive papillary tumours that frequently recur but seldom invade. In contrast, deletions or mutations of the TP53, and other important suppressor genes $(R B 1, E R B B 2$, or PTEN), are related to the development of muscle-invasive bladder cancer and carcinoma in situ (Knowles and Hurst 2014).

It is known that p53 protein is stabilized and activated in response to various genotoxic stresses to induce cell cycle arrest, DNA repair, and apoptosis. Hence, the induction of DNA damage by chemotherapy and radiotherapy to stabilize p53 is a promising strategy to induce apoptotic cell death in malignant tumours. However, p53 is mutated in half of the human cancers and the mt-p53 loses its function that causes drug resistance (Dashzeveg et al. 2016).

Thus, the presence of a functional TP53 is associated with a good response to chemotherapy (Vinall et al. 2012), and impacts the clinical decisions regarding adjuvant therapy (Zhang et al. 2013). Indeed, compelling evidence shows that the mutational spectrum of cancer genome can strongly influence the patient's cancer response to treatment (Garnett et al. 2012).

We observed that silibinin was able to increase the primary DNA damage at the highest concentration (150 $\mu \mathrm{M})$ in both wild-type and mutated TP53 bladder cancer cells. The genotoxic potential of silibinin was previously demonstrated in oral carcinoma (KB), hepatoma (HepG2), and osteosarcoma cell lines through a mechanism that involves mitochondrial stress and ROS generation (Angeli et al. 2010; Gohulkumar et al. 2014; Leon et al. 2014). Moreover, such stress can alter the mitochondrial membrane potential, leading to apoptosis (Gohulkumar et al. 2014).

Here, we observed that silibinin decreased cell proliferation only in TP53 mutated cells, 2 days after treatment with the highest concentrations $(150-250 \mu \mathrm{M})$. On the other hand, the clonogenic survival assay revealed in both cell lines a significant decrease in cell colonies formation 15 days after silibinin treatment at all tested concentrations. Similarly, it has been reported that silibinin treatment inhibited metabolic activity and clonogenic potential of human neuroblastoma (SK-N-MC) cells in a dose-dependent manner (Yousefi et al. 2012).

Taken together, these results provide evidence that silibinin promotes reduction of the number of cell colonies, most likely because of DNA damage induction. However, despite its genotoxic potential, no effect of silibinin was observed on RT4 cell proliferation $48 \mathrm{~h}$ after exposure. Interestingly, it was previously demonstrated that silibinin may modulate nucleotide excision repair (NER) process in proficient TP53 wild-type fibroblast cells through the increase of p53 and GADD $45 \alpha$ expression, both key regulators of NER pathway (Guillermo-Lagae et al. 2015). Perhaps in RT4 cells, the acute exposure to silibinin may have a protective effect. It is important to highlight that the clonogenic potential measured by the clonogenic survival assay is a very relevant endpoint to be evaluated, since cells unable to 

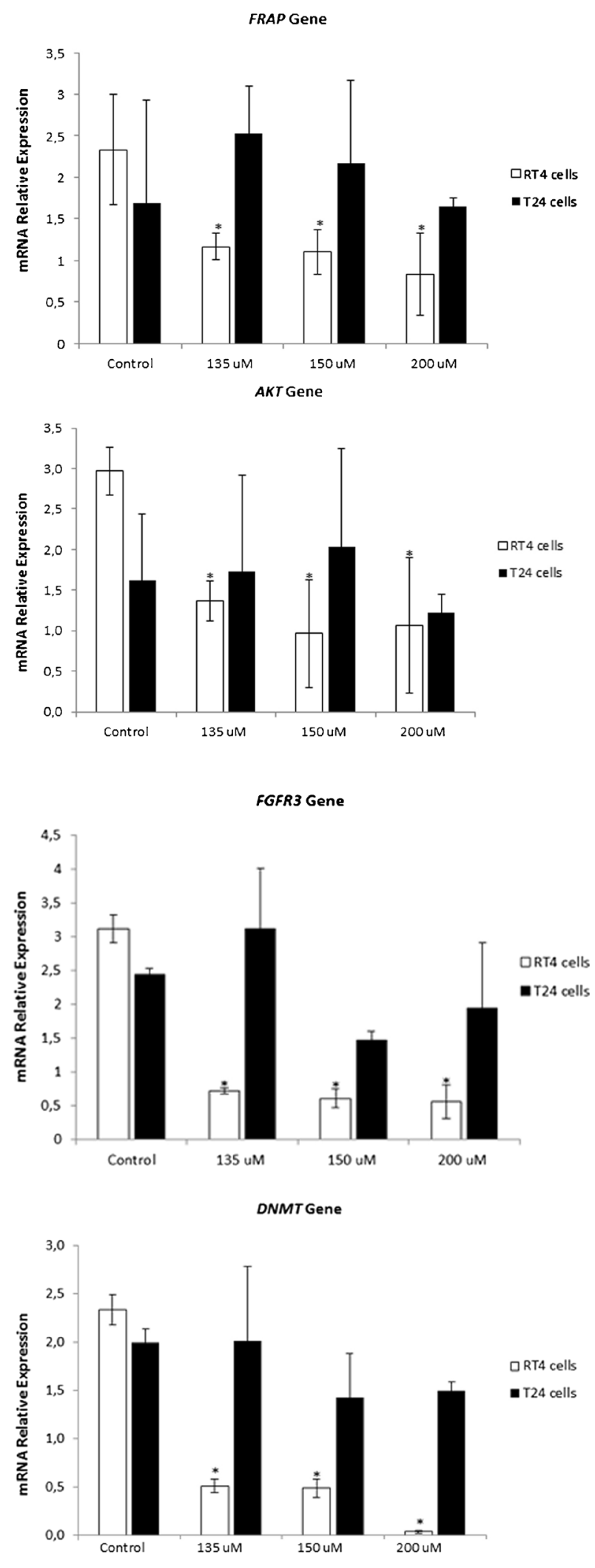

produce colonies are also unlikely to produce tumours (Tannock et al. 2001). The chronic response of both cell lines evaluated 15 days after silibinin treatment (clonogenic assay) was characterized by a significant decrease in colonies formation, suggesting that such compound may alter the cell reproductive potential.

Thus, considering that silibinin was not genotoxic in lower concentrations, these findings may suggest that other mechanisms than DNA damage are primarily responsible for the silibinin effect on cell proliferation (clonogenic potential). Additionally, we noted that acute response to silibinin involves the induction of cell death through $\mathrm{p} 53$-independent pathways, since early $(250 \mu \mathrm{M})$ and late $(100,150,200$ and $250 \mu \mathrm{M})$ apoptosis were detected in T24, and only early $(200 \mu \mathrm{M})$ apoptosis in RT4 cells. It has been suggested (Tyagi et al. 2004) that the selectivity and specificity of silibinin-induced apoptosis in two UCC cell lines (TCC-SUP and T24), showing a dose- and time-dependent apoptotic death only in TCC-SUP cells, associated with the cleaved forms of caspase 3 and poly(ADP-ribose) polymerase. Furthermore, while silibinin suppressed tumour growth and induced apoptosis by the $\mathrm{Bax} / \mathrm{Bcl}-2$ pathway through caspases activation in human endothelial cells (ECV304) (Yoo et al. 2004), in human hepatocellular (HuH7) and renal carcinoma (Caki-1) cells, this compound promoted apoptosis by down-regulating survivin (Li et al. 2008; Cui et al. 2009). Thereby, it is possible to believe that silibinin induces apoptosis through cellular-specific mechanisms.

To better understand silibinin mechanisms of action, its acute effects on expression of genes related to cellular proliferation, invasion and migration (PI3K/AKT and PI3K/FRAP-mTOR pathways) and DNA methylation $(D N M T 1)$ were also investigated. Down-regulation of $F R A P / \mathrm{mTOR}, F G F R 3$ and AKT2 gene expression in TP53 wild-type cells (RT4) was detected. These findings suggest inhibition of the PI3K/AKT/FRAP-mTOR pathway, decreasing clone formation and increasing cell death, possibly through p53 mechanism. Indeed, simultaneous pharmacological modulation of $\mathrm{p} 53$ and AKT/mTOR pathway could provide enhanced anticancer efficacy through cell proliferation and growth inhibition (Budanov and Karin 2008; Levine and Oren 2009). However, silibinin could have also acted through different mechanisms, since reduced clone formation without gene expression modulation was observed in mutated TP53 cells (T24). Since TP53 acts as a molecular node, modulation of cell response could also be caused by

4Figure 5. Relative expression of $F R A P / \mathrm{mTOR}$ and $A K T 2, F G F R 3$ and DNMT1 genes in RT4 and T24 cells treated with silibinin. Each column represents the mean value \pm standard deviation obtained from three independent treatments with the same concentration of silibinin. Control - treated with 2\% DMSO (control vehicle); $* p<0.05$ compared with control. 
98
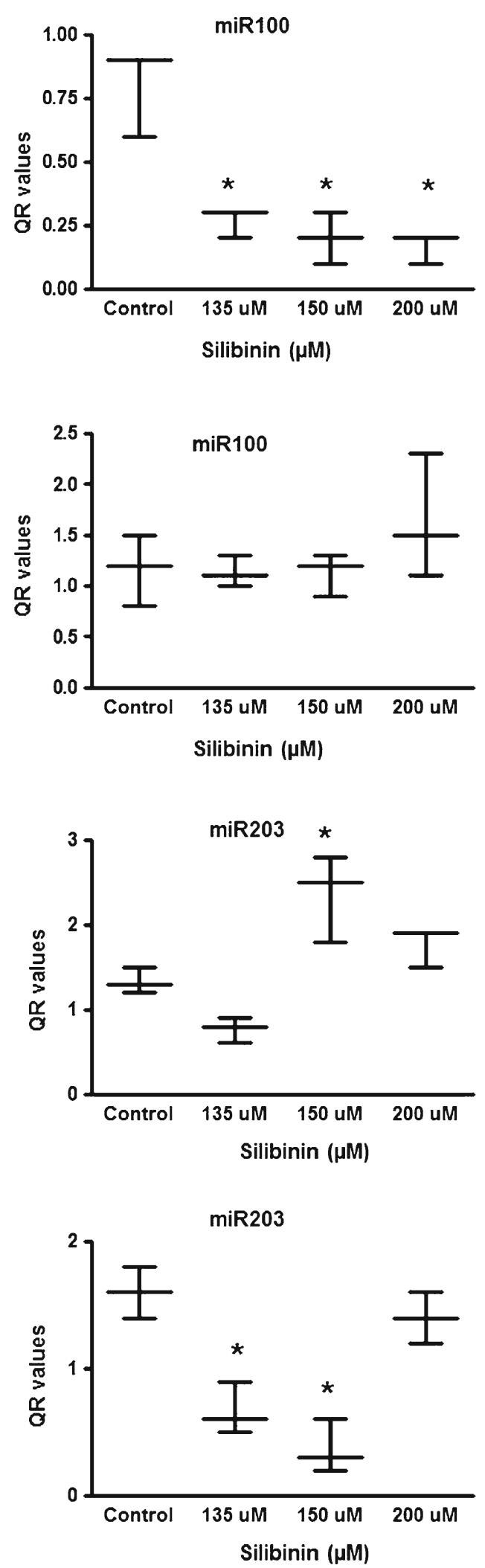

Figure 6. Relative expression of miR100 and miR203 in RT4 and T24 cells treated with silibinin. Control - treated with $2 \%$ DMSO (vehicle control). Cell cultures were performed in triplicate.

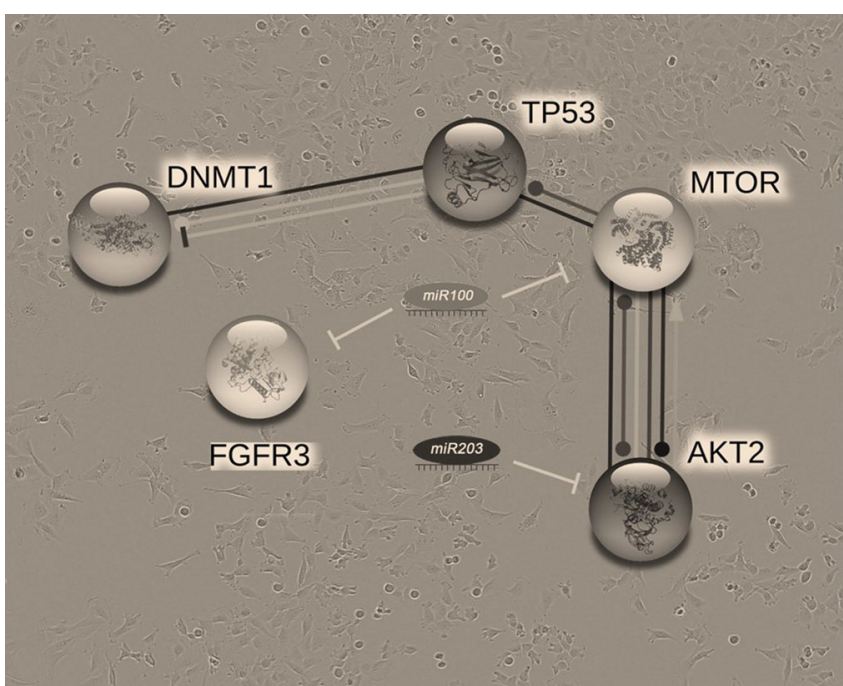

Figure 7. Gene network created using in silico data from String 10 software. Continuous lines represent gene interactions. Lines with arrows indicate gene activation and with lines with balls indicate post-transcriptional activation.

other altered target genes. In a previous study we reported that gene networks of three cell lines of UCC (RT4, 5637 and T24), determined by Bayesian interpolation, showed interactions among TP53 and several other genes, suggesting that other pathways might be associated with the malignant phenotype (da Silva et al. 2010).

The down-regulation of DNMT1 only in the TP53 wildtype cells (RT4) may indicate a decrease of genome methylation, with consequent activation of genes that should be silenced, such as tumour suppressor genes. Recently it was demonstrated that DNMTs inhibition can arrest tumour growth and cells invasiveness and induce differentiation; however, their increased expression was shown in numerous cancer types (Zwergel et al. 2016). In fact, Fang et al. (2015) have found an up-regulation of DNMT1 in hepatocellular carcinoma cells. These authors demonstrated that cells with active AKT mechanism show de novo DNA methylation and up-regulation of DNA methyltransferase 1 via an AKT/ $\beta$ transducin repeat-containing protein $(\beta \mathrm{TrCP})$-mediated ubiquitin-proteasome pathway. In our study, both $A K T$ and DNMT1 expression were inhibited in RT4 cells, suggesting that the antiproliferative effects could also be due to simultaneous modulation of these genes.

Another mechanism investigated was the effect of silibinin on relative expression of two microRNAs (miR203 and $m i R 100)$ involved in the post-transcriptional regulation of Akt2/mTOR, FGFR3 and FRAP genes. Dysregulation of $m i R 100$ and $m i R 203$ has been reported to be involved in tumorigenesis and tumour progression of several cancer types. However, its expression patterns in tumours are controversial (Nagaraja et al. 2010; Saini et al. 2011; Wang 
et al. 2013). In our study, since FGFR3 gene was downregulated in wild-type TP53 cells, we were expecting miR100 to be up-regulated, but the results showed downregulation of this miRNA. Some authors corroborate our results, suggesting that other mechanisms besides PI3KFRAP/mTOR must be involved in the toxicogenomic effect of silibinin. Gong et al. (2015) showed that silencing miR100 expression with anti-miRNA-100 oligonucleotide initiated apoptosis of breast cancer SK-BR-3 cells in vitro and in vivo, suggesting down-regulation of miR100-sensitized breast cancer cells to chemotherapy. miR203 upregulation was observed in RT4 cells and down-regulation was observed in T24 cells, but not at all concentrations, suggesting that the expression does not depend on TP53 status. Rihani et al. (2015) did not observe direct binding of p53 to miR203 in neuroblastoma cells. Thus, the miR100 and miR203 function in predicting the effect of silibinin still needs to be clarified.

In conclusion, despite silibinin inhibiting clone formation and activating apoptosis in both wild-type and TP53 mutated bladder cancer cell lines, modulation of $F R A P / \mathrm{mTOR}$, $A K T 2, F G F R 3$ and DNMT1 expression occurred in a TP53-status-dependent way. However, although the results show promise regarding the important role of silibinin as an antiproliferative compound, further in vivo studies that include the complexity of living body need to be performed to better understand the mechanisms by which silibinin exerts its antineoplastic activity.

\section{Acknowledgements}

This study was supported by Fundação de Amparo à Pesquisa do Estado de São Paulo (FAPESP-2008/09147-6), Fundação de Amparo à Pesquisa do Estado de Minas Gerais (CBB-APQ-01497-14), Conselho Nacional de Desenvolvimento Científico e Tecnológico (CNPq-441836/2014-3) and Universidade Federal de Ouro Preto (UFOP).

\section{References}

Ahmad A, Sakr WA and Rahman KMW 2012 Novel targets for detection of cancer and their modulation by chemopreventive natural compounds. Front. Biosci. Elite 4 410-425

Angeli JPF, Barcelos GRM, Serpeloni JM, Barbosa F, Nersesyan A and Mantovani MS 2010 Evaluation of the genotoxic and anti-genotoxic activities of silybin in human hepatoma cells (HepG2). Mutagenesis 25 223-229

Aravindaram K and Yang NS 2010 Anti-inflammatory plant natural products for cancer therapy. Planta Med. 76 1103-1117

Bartel DP 2004 MicroRNAs: genomics, biogenesis, mechanism, and function. Cell 116 281-297
Budanov AV and Karin M 2008 p53 target genes sestrin1 and sestrin2 connect genotoxic stress and mTOR signaling. Cell 134 451-460

Chawla RMP, Gupta D, Juneja M, Kumar R, Sharma A, Baliga MS, Sharma PK, Tripathi RP and Arora R 2010 Herbal medicine a cancer chemiopreventive and therapeutic perspective (Jaypee Brothers Medical Publishers)

Cheng L, Zhang S, MacLennan GT, Williamson SR, Lopez-Beltran A and Montironi R 2011 Bladder cancer: translating molecular genetic insights into clinical practice. Hum. Pathol. 42 455-481

Cui W, Gu F and Hu KQ 2009 Effects and mechanisms of silibinin on human hepatocellular carcinoma xenografts in nude mice. World J. Gastroenterol. 15 1943-1950

da Costa NM, Hautefeuille A, Cros MP, Melendez ME, Waters T, Swann P, Hainaut P and Pinto LF 2012 Transcriptional regulation of thymine DNA glycosylase (TDG) by the tumor suppressor protein p53. Cell Cycle 11 4570-4588

da Silva GN, Marcondes JPC, de Camargo EA, Passos Júnior G, Sakamoto-Hojo ET and Salvadori DMF 2010 Cell cycle arrest and apoptosis in TP53 subtypes of bladder carcinoma cell lines treated with cisplatin and gemcitabine. Exp. Biol. Med. 235 814-824

Dashzeveg N, Yogosawa S and Yoshida K 2016 Transcriptional induction of protein kinase $\mathrm{C}$ delta by $\mathrm{p} 53$ tumor suppressor in the apoptotic response to DNA damage. Cancer Lett. 374 167-174

Dobbin Z and Landen C 2013 The Importance of the PI3K/AKT/ MTOR Pathway in the Progression of Ovarian Cancer. Int. J. Mol. Sci. 14 8213-8227

Dumont P, Ingrassia L, Rouzeau S and Ribaucour R 2007 The Amaryllidaceae isocarbostyril Narciclasine induces apoptosis by activation of the death receptor and/or mitochondrial pathways in câncer cells but not in normal fibroblasts. Neoplasia. 9 766-767

Esuvaranathan K, Chiong E, Thamboo TP, Chan YH, Kamaraj R and Mahendran R 2007 Predictive value of p53 and pRb expression in superficial bladder cancer patients treated with $\mathrm{BCG}$ and interferon-alpha. Cancer 109 1097-1105

Fang QL, Yin YR, Xie CR, Zhang S, Zhao WX and Pan C 2015 Mechanistic and biological significance of DNA methyltransferase 1 upregulated by growth factors in human hepatocellular carcinoma. Int. J. Oncol. 46 782-790

Garnett MJ, Edelman EJ, Heidorn SJ, Greenman CD, Dastur A, Lau KW, Greninger P, Thompson IR, et al. 2012 Systematic identification of genomic markers of drug sensitivity in cancer cells. Nature 483 570-575

Gingras AC, Raught B and Sonenberg N 2001 Regulation of translation initiation by FRAP/mTOR. Genes Dev. 15 807-826

Gohulkumar M, Gurushankar K, Rajendra Prasad N and Krishnakumar N 2014 Enhanced cytotoxicity and apoptosis-induced anticancer effect of silibinin-loaded nanoparticles in oral carcinoma (KB) cells. Mater. Sci. Eng. C. 41 274-282

Gong Y, He T, Yang L, Yang G, Chen Y and Zhang X 2015 The role of miRNA-100 in regulating apoptosis of breast cancer cells. Sci. Rep. 5 11650-11663

Gonzalez-Angulo AM and Blumenschein GR 2013 Defining biomarkers to predict sensitivity to PI3K/Akt/mTOR pathway inhibitors in breast cancer. Cancer Treat. Rev. 39 313-320

Guillermo-Lagae R, Deep G, Ting H, Agarwal C and Agarwal R 2015 Silibinin enhances the repair of ultraviolet B-induced DNA 
damage by activating p53-dependent nucleotide excision repair mechanism in human dermal fibroblasts. Oncotarget 639594 39606

Halberstein RA 2005 Medicinal plants: historical and cross-cultural usage patterns. Ann. Epidemiol. 15 686-699

Jemal A, Siegel R, Ward E, Murray T and Xu J 2007 Thun, Cancer statistics. CA Cancer J. Clin. 57 43-66

Kauntz H, Bousserouel S, Gossé F and Raul F 2013 Epigenetic effects of the natural flavonolignan silibinin on colon adenocarcinoma cells and their derived metastatic cells. Oncol. Lett. 5 1273-1277

Kaur M, Velmurugan B, Tyagi A, Deep G, Katiyar S and Agarwal C 2009 Silibinin suppresses growth and induces apoptotic death of human colorectal carcinoma LoVo cells in culture and tumor xenograft. Mol. Cancer Ther. 8 2366-2374

Knowles MA and Hurst CD 2014 Molecular biology of bladder cancer: new insights into pathogenesis and clinical diversity. Nature Rev. Cancer 15 25-41

Kumar S, Raina K, Agarwal C and Agarwal R 2014 Silibinin strongly inhibits the growth kinetics of colon cancer stem cellenriched spheroids by modulating interleukin 4/6-mediated survival signals. OncoTarget 5 4972-4989

Leon IE, Porro V, Di Virgilio AL, Naso LG, Williams PAM and Bollati-Fogolín M 2014 Antiproliferative and apoptosisinducing activity of an oxidovanadium(IV) complex with the flavonoid silibinin against osteosarcoma cells. J. Biol. Inorg. Chem. 19 59-74

Levine AJ and Oren 2009 The first 30 years of p53: growing ever more complex. Nat. Rev. Cancer 9 749-758

Li L, Gao Y, Zhang L, Zeng J, He D and Sun Y 2008 Silibinin inhibits cell growth and induces apoptosis by caspase activation, down-regulating survivin and blocking EGFR-ERK activation in renal cell carcinoma. Cancer Lett. 272 61-69

Li DW, Sun JY, Wang K, Zhang S, Hou YJ and Yang MF 2015 Attenuation of cisplatin-induced neurotoxicity by cyanidin, a natural inhibitor of ROS-mediated apoptosis in PC12 cells. Cell Mol. Neurobiol. 35 995-1001

Livak KJ and Schmittgen TD 2001 Analysis of relative gene expression data using real-time quantitative PCR and the 2(-Delta Delta $\mathrm{C}(\mathrm{T})$ ) Method. Methods 25 402-408

Luo J, Manning BD and Cantley LC 2003 Targeting the PI3K-Akt pathway in human cancer: rationale and promise. Cancer Cell 4 257-262

Maiti A and Drohat AC 2011 Thymine DNA glycosylase can rapidly excise 5-formylcytosine and 5-carboxylcytosine: potential implications for active demethylation of $\mathrm{CpG}$ sites. J. Biol. Chem. 286 35334-35338

Mateen S, Raina K, Agarwal C, Chan D and Agarwal R 2013 Silibinin synergizes with histone deacetylase and DNA methyltransferase inhibitors in upregulating E-cadherin expression together with inhibition of migration and invasion of human nonsmall cell lung cancer cells. J. Pharmacol. Exp. Ther. 345 206-214

Mayr R, Fritsche HM, Pycha A and Pycha A 2014 Radical cystectomy and the implications of comorbidity. Expert. Rev. Anticancer Ther. 14 289-295

Moseley VR, Morris J, Knackstedt RW and Wargovich MJ 2013 Green tea polyphenol epigallocatechin 3-gallate, contributes to the degradation of DNMT3A and HDAC3 in HCT 116 human colon cancer cells. Anticancer Res. 33 5325-5333
Nagaraja AK, Creighton CJ, Yu Z, Zhu H, Gunaratne PH and Reid JG 2010 A link between mir-100 and FRAP1/mTOR in clear cell ovarian cancer. Mol. Endocrinol. 24 447-463

Patel SG, Cohen A, Weiner AB and Steinberg GD 2015 Intravesical therapy for bladder cancer. Expert. Opin. Pharmacother. 16 889-901

Philippou Y, Hadjipavlou M, Khan S and Rane A 2013 Complementary and alternative medicine (CAM) in prostate and bladder cancer. BJU Int. 112 1073-1079

Raghavan D, Burgess E, Gaston KE, Haake MR and Riggs SB 2012 Neoadjuvant and adjuvant chemotherapy approaches for invasive bladder cancer. Semin. Oncol. 39 588-597

Raina K, Agarwal C and Agarwal R 2013 Effect of silibinin in human colorectal cancer cells: targeting the activation of NF-KB signaling. Mol. Carcinog. 52 195-206

Rajamanickam S, Velmurugan B, Kaur M, Singh RP and Agarwal R 2010 Chemoprevention of intestinal tumorigenesis in APCmin/+ mice by silibinin. Cancer Res. 70 2368-2378

Retz M, Schmid SC, Kramer MW and Merseburger AS 2013 Systemische Therapie des metastasierten Blasenkarzinoms. Urology 52 1541-1546

Rihani A, Van Goethem A, Ongenaert M, De Brouwer S, Volders PJ, Agarwal S, De Preter K, Mestdagh P, et al. 2015 Genome wide expression profiling of $\mathrm{p} 53$ regulated miRNAs in neuroblastoma. Sci. Rep. 5. doi:10.1038/srep09027

Saini S, Arora S, Majid S, Shahryari V, Chen Y and Deng G 2011 Curcumin modulates microRNA-203-mediated regulation of the Src-Akt axis in bladder cancer. Cancer Prev. Res. 4 1698-1709

Saint F, Le Frere Belda MA, Quintela R, Hoznek A, Patard JJ and Bellot J 2004 Pretreatment p53 nuclear overexpression as a prognostic marker in superficial bladder cancer treated with Bacillus Calmette-Guérin (BCG). Eur. Urol. 45 475-482

Sávio ALV, da Silva GN and Salvadori DMF 2015 Inhibition of bladder cancer cell proliferation by allyl isothiocyanate (mustard essential oil). Mutat. Res. 771 29-35

Shaw RJ and Cantley LC 2006 Ras PI(3)K and mTOR signalling controls tumour cell growth. Nature 441 424-430

Singh NP, McCoy MT, Tice RR and Schneider EL 1988 A simple technique for quantitation of low levels of DNA damage in individual cells. Exp. Cell Res. 175 184-197

Sinha S, Jothiramajayam M, Ghosh M, Jana A, Chatterji U and Mukherjee A 20152015 Vetiver oil (Java) attenuates cisplatininduced oxidative stress, nephrotoxicity and myelosuppression in Swiss albino mice. Food Chem. Toxicol. 81 120-128

Suzuki HI, Yamagata K and Sugimoto K 2009 Modulation of microRNA processing by p53. Nature 460 529-533

Tannock IF, Lee C 2001 Evidence against apoptosis as a major mechanism for reproductive cell death following treatment of cell lines with anti-cancer drugs. Br. J. Cancer 84 100-105

Tice RR, Andrews PW, Hirai O and Singh NP 1991 The single cell gel (SCG) assay: an electrophoretic technique for the detection of DNA damage in individual cells. Adv. Exp. Med. Biol. 283 157-164

Ting H, Deep G and Agarwal R 2013 Molecular mechanisms of silibinin-mediated cancer chemoprevention with major emphasis on prostate cancer. AAPS J. 15 707-716

Tyagi A, Agarwal C, Harrison G, Glode LM and Agarwal R 2004 Silibinin causes cell cycle arrest and apoptosis in human bladder 
transitional cell carcinoma cells by regulating CDKI-CDKcyclin cascade, and caspase 3 and PARP cleavages. Carcinogenesis 25 1711-1720

Tyagi A, Raina K, Singh RP, Gu M, Agarwal C and Harrison G 2007 Chemopreventive effects of silymarin and silibinin on N-butyl-N(4-hydroxybutyl) nitrosamine induced urinary bladder carcinogenesis in male ICR mice. Mol. Cancer Ther. 6 3248-3255

van Lingen AV, Arends TJH and Witjes JA 2013 Expert review: an update in current and developing intravesical therapies for nonmuscle-invasive bladder cancer. Expert. Rev. Anticancer. Ther. 13 1257-1268

Vinall RL, Ripoll AZ, Wang S, Pan CX and deVere WRW 2012 MiR34a chemosensitizes bladder cancer cells to cisplatin treatment regardless of p53-Rb pathway status. Int. J. Cancer. $1302526-2538$

Wang G, Chen L, Meng J, Chen M, Zhuang L and Zhang L 2013 Overexpression o f miRNA-100 predicts an unfavorable prognosis in renal cell carcinoma. Int. Urol. Nephrol. 45 373-379

Weng JR, Lai IL, Yang HC, Lin CN and Bai LC 2014 Identification of kazinol Q, a natural product from Formosan plants, as an inhibitor of DNA methyltransferase. Phytother. Res. 28 49-54
Wu L and Belasco JG 2008 Let me count the ways: mechanisms of gene regulation by miRNAs and siRNAs. Mol. Cell 2 1-7

Yoo HG, Jung SN, Hwang YS, Park JS, Kim MH and Jeong M 2004 Involvement of NF-kappaB and caspases in silibinin-induced apoptosis of endothelial cells. Int. J. Mol. Med. 13 81-86

Yousefi M, Ghaffari SH, Soltani BM, Nafissi S, Momeny M, Zekri A, Behmanesh M, Alimoghaddam K, et al. 2012 Therapeutic efficacy of silibinin on human neuroblastoma cells: Akt and NF$\kappa \mathrm{B}$ expressions may play an important role in silibinin-induced response. Neurochem. Res. 37 2053-2063

Zeng J, Sun Y, Wu K, Li L, Zhang G and Yang Z 2011 Chemopreventive and chemotherapeutic effects of intravesical silibinin against bladder cancer by acting on mitochondria. Mol. Cancer Ther. 10 104-116

Zhang Y, Yan L, Zhao Y, Ou L, Wu X and Luo C 2013 Knockdown of Phospholipase C-epsilon by short-hairpin RNA-mediated gene silencing induces apoptosis in human bladder cancer cell lines. Cancer Biother. Radiopharm. 28 233-239

Zwergel C, Valente S and Mai A 2016 DNA methyltransferases inhibitors from natural sources. Curr. Top. Med. Chem. 16 680-696

MS received 22 August 2016; accepted 24 October 2016

Corresponding editor: SoRAB N DALAL 